\title{
NOSTALGICZNE KINO WIERY STOROŻEWEJ I PAWŁA ŁUNGINA (NA PODSTAWIE FILMÓW PODRÓŻ ZE ZWIERZĘTAMI DOMOWYMI I TAXI BLUES)
}

\author{
NOSTALGIC CINEMA OF VERA STOROZHEVA AND PAVEL LUNGIN \\ (ON THE BASIS OF THE FILMS TRAVELLING WITH PETS \\ AND TAXI BLUES)
}

BEATA WALIGÓRSKA-OLEJNICZAK

\begin{abstract}
The article presents the interpretation of two Russian films, Travelling with Pets by Vera Storozheva and Taxi Blues by Pavel Lungin, from the point of view of the category of nostalgia. The article shows that the heroes of both artistic texts function in the hybrid reality, the collapse of the old world accompanies their search for the wholeness and new identity. Travelling with Pets emphasizes the spatial dimension of the experience, whereas Taxi Blues transforms it into the vision of the relationship with time, the continuum of past, present and future, which corresponds with the triad: history-memory-nostalgia.
\end{abstract}

Keywords: nostalgia, Storozheva, Lungin, memory, history, nostalgic cinema

Beata Waligórska-Olejniczak, Uniwersytet im. Adama Mickiewicza w Poznaniu, Poznań Polska, beata.waligorska@amu.edu.pl

ORCID ID: 0000-0002-0433-9920

Charles Maier wyraził niegdyś opinię, że nostalgia jest tym dla pamięci, czym kicz dla sztuki, jest historią bez poczucia winy [1999: 273]. Swietłana Boym nazwała nostalgię symptomem i utopią naszych czasów, a jedna z czołowych badaczek postmodernizmu Linda Hutcheon określiła kulturę współczesną mianem kultury nostalgicznej, przyglądając się jej przez pryzmat problemu ironii [Boym 2001; Hutcheon 2000]. Z punktu widzenia zjawiska pastiszu analizował z kolei nostalgię Fredric Jameson, który jako pierwszy zauważył obecność nurtu nostalgicznego w kinie lat 70. i 80. XX wieku, $\mathrm{w}$ filmach skierowanych przede wszystkim do masowego odbiorcy. Łatwo zauważyć, że pod koniec minionego stulecia nostalgia nie jest już problemem czy przypadłością nieradzącej sobie z życiem, rozdartej jednostki, ale zjawiskiem kulturowym, wpisanym na stałe w pamięć zbiorową. Niektórzy wiążą tę swoistą intensyfikację zainteresowania nostalgią z twórczym kryzysem ery postmodernizmu. Rosyjska badaczka Tatiana W. Bakina w swych rozważaniach nad wybranym fenomenem kultury zwraca uwagę na istotne 
różnice między nostalgią a rosyjską tęsknotą (ros. mocka), kojarzoną przeważnie z nudą, chandrą czy smutkiem, podczas gdy kategoria nostalgii winna przywodzić na myśl asocjacje z brakiem i utratą, domem, zapamiętanym wrażeniem zmysłowym, ulokowanym $\mathrm{w}$ danej przestrzeni lub czasie, który już nigdy nie wróci, stąd nieodzownie towarzyszy jej mitologizacja i idealizacja zjawisk minionych [2014].

Przystępując do rozważań nad obecnością nostalgii we współczesnym kinie rosyjskim warto zwrócić uwagę na obserwowany dziś niemalże we wszystkich sferach kultury zwrot ku retrospekcji, czego wyrazem są między innymi idee oparte na recyklingu, symulacji, (re)produkcji, kontaminacji czy cytowaniu. $\mathrm{W}$ tendencje te perfekcyjnie wpisuje się propozycja Jamesona, by kino nostalgiczne rozumieć jako filmy bliskie francuskiemu stylowi la mode retro, przypominającemu widzowi atmosferę dawnych czasów przy użyciu materialnych atrybutów danej epoki. Część badaczy ową materialność uznaje za niezbędny składnik zjawiska nostalgii, tłumacząc tym jednocześnie niezwykłą popularność w ostatnim czasie i wyróżnianie prestiżowymi, festiwalowymi nagrodami takich filmów jak Artysta (The Artist, 2011) Michela Hazanaviciusa, Hugo i jego wynalazek (Hugo, 2011) Martina Scorsese, Hitchcock (2012) Sachy Gervasi'ego oraz rozwój mockumentów. Odrębną grupę w klasyfikacji dzieł nostalgicznych powinny chyba stanowić obrazy czerpiące garściami z bogatej historii kina i eksperymentów filmowych, do których należałoby zaliczyć także wspomnianego już Artystę i cały niemalże dorobek Quentina Tarantino, pełen intertekstualnych gier i wizualnych odniesień do osiągnięć światowej kinematografii.

Celem niniejszego tekstu jest przedstawienie propozycji interpretacji dwóch filmów rosyjskich, tj. obrazu Wiery Storożewej Podróż ze zwierzętami doтошуті (Путешествие с домашними животными, 2007) oraz Taxi Blues (Такси-блюз, 1990) Pawła Łungina z punktu widzenia kategorii nostalgii. W percepcji problemu zamierzam wyjść poza dość wąsko zdefiniowany przez Jamesona termin kino nostalgiczne, kontekstualizowany przez teoretyka głównie w odniesieniu do współczesnych wariantów filmu historycznego. Za modelowe przykłady odzwierciedlające założenia Jamesona mogłyby też służyć filmy Woody’ego Allena, kręcone według swoistej matrycy, składające się na jego cykl miejski. Moim rozważaniom patronować będą przede wszystkim spostrzeżenia Freda Davisa, dokonującego rozróżnienia między nostalgią prywatną (bazującą na pamięci i biografii konkretnej jednostki) a nostalgią zbiorową (opartą na doświadczeniach, składających się na tożsamość kulturową całych grup, spojonych wspólną historią) oraz typologia Swietłany Boym, wyróżniającej nostalgię restauracyjną i refleksyjną, inaczej zwaną ironiczną [Boym 2001; Davis 1979]. W ujęciu Boym, co okaże się intelektualnie płodne dla dalszych rozważań, nostalgia może oznaczać także tęsknotę za 
przyszłością, paralelnymi możliwościami, które z różnych przyczyn zostały utracone i niezrealizowane. Warto przy tym pamiętać, że nostalgia nie zawsze związana jest ze stanem pasywnym, wynikającym z poczucia braku czy niespełnienia, pierwotnie, o czym przypomina w swych rozważaniach Przemysław Czapliński, wiązano ją z aktywnością, ocalającym powrotem do domu (greckie nostos), to modernizm przesunął akcent na algos (ból utęsknienia) [2001: 5-9].

Wydaje się, że wybrane do interpretacji obrazy filmowe w sposób niemal komplementarny uświadamiają wspomnianą wyżej biegunowość pojęcia. Można postawić tezę, że film Storożewej stanowi dla widza propozycję refleksji nad aktywnym wariantem nostalgii, kończy się bowiem metaforycznie ujętym odnalezieniem domu jako świata w swej pełni, złożonej z harmonijnie scalonych fragmentów. Łungin w ostatniej sekwencji pościgu i wybuchu samochodów niemalże dosłownie prezentuje ciemną stronę nostalgii, rozpad marzeń i iluzji bohatera żyjącego w rzeczywistości zbudowanej na fałszu. Oba filmy, mimo że powstały ponad 10 lat temu, doskonale pokazują także niezwykle aktualny dziś problem poszukiwania dziejowego continuum, stabilnej podstawy egzystencji w obliczu chwiejności układów geopolitycznych i elastyczności norm moralnych, uzasadniając tym samym konieczność rewizji badań nad dynamicznie rozwijającymi się trendami nostalgicznymi w literaturze, filmie i sztukach plastycznych.

Krytycy, przyglądając się filmowi Podróż ze zwierzętami domowymi, najczęściej poszukują odpowiedzi na pytanie, co jest głównym problemem obrazu Storożewej, niemal jednogłośnie diagnozując przy tym, że stanowi go przede wszystkim kwestia wolności osobistej, a szczególnie rola i wybory życiowe kobiety [Monastireva-Ansdell 2008]. W zgodzie ze wspomnianym, po części socjologicznym, postrzeganiem filmu pozostają interpretacje dokonywane w tzw. duchu feminizmu, których autorzy uznali dzieło reżyserki za modelowy manifest tego nurtu. Istotnymi jawią się komentarze wydobywające na pierwszy plan aktywną, pozbawioną sentymentalizmu, postawę protagonistki, która nie rozczula się nad sobą po śmierci męża, nikogo nie obwinia za to, co ją w życiu spotyka, ale bierze życie w swoje ręce i świadomie o nim decyduje, odtrącając ze wszech miar racjonalną propozycję przystojnego Siergieja. Pod pewnymi względami Natalię można by więc uznać za bohaterkę antyrosyjską, w otaczającej ją patriarchalnej rzeczywistości prezentuje się bowiem jako silna indywidualistka, zdeterminowana, by zrealizować swój „biznes plan", którego wieńczącym zadaniem jest adopcja dziecka.

Byłaby to jednak ocena bardzo myląca i powierzchowna, w rzeczywistości bowiem jej życie zdaje się realizować w przebudzonej do życia sferze duchowej, w dojrzałej i świadomie rozwijanej seksualności, w kontemplacji przyrody, dziecięcym, naiwnym zachwycie nad mało znaczącymi wydarzeniami 
i namyśle nad samą sobą, kobietą odczuwającą puls świata, matką-ziemią. O tej ostatniej hipostazie kobiecości świadczą w głównej mierze ciągi kadrów ukazujące Natalię w podróży do domu dziecka. Na pierwszy rzut oka wydawać się może, że to dopiero podróż powrotna z synem i psem jest momentem osiągnięcia spełnienia przez bohaterkę, nostalgicznym powrotem ocalającym, którego zapowiedź i w pewnym sensie lustrzane odbicie stanowią kadry przedstawiające korowód ślubny, pokonujący most. W obu przypadkach reżyserka wyraźnie zaznacza moment przejścia, pokonywania granicy i bycia w drodze, dodatkowo zaakcentowany obecnością mostu, zyskującego tutaj status symbolu zdegradowanego niemal do poziomu czytelnej, jednowymiarowej alegorii. Korowód, budzący skojarzenia z karnawałową maskaradą, przywodzący na myśl również asocjacje z trójcą (panna młoda, małżonek i ich żyjące $w$ łonie matki dziecko), stanowi jednak przewrotny znak fałszu. Ciążowe zaokrąglenia kobiety, sztuczność wydarzenia akcentowana między innymi głośnym śmiechem przechodniów i ich strojami, pozwala traktować podróż Natalii jako znacznie bardziej autentyczną i optymistyczną prognozę na przyszłość. Bohaterka osiąga zresztą wewnętrzną harmonię, swój wirtualny dom, dużo wcześniej, podejmując świadomą i wyzwalającą decyzję o adopcji, co zdają się sugerować zbliżenia jej twarzy w trakcie podróży łodzią, przedstawiające wizerunek bohaterki wyraźnie stylizowany na ikonę Matki Bożej (dominująca obecność błękitu w kolorystyce zdjęć, długie, monotonne, podobne do siebie ujęcia, wprowadzające atmosferę zadumy i kojącego bezruchu).

Badacze kategorii nostalgii często wskazują na fakt, że wzrost nastrojów nostalgicznych obserwowany jest szczególnie po okresach gwałtownych zmian, rewolucjach i innych przełomowych wydarzeniach historycznych. Przełożeniem tego typu zdarzeń w życiu protagonistki jest śmierć męża, która pozwala jej dojrzeć niezrealizowane możliwości. Bohaterka, choć nie mogła zajść w ciążę z małżonkiem, odrzuca także - na rzecz adopcji - szansę noszenia dziecka Siergieja, w rezultacie czego jest w stanie przepracować swoje traumatyczne doświadczenia z domu dziecka, z którego wielokrotnie uciekała. Podróżując po latach do miejsca dziecięcych cierpień, dokonuje rekonstrukcji tej przestrzeni, nadaje jej status domu, którego nigdy nie miała. Miłość do zaadaptowanego syna przemienia ją w miejsce utopijne, które nigdy nie istniało. Można skonstatować, że powracając do domu dziecka i zabierając z niego chłopca Natalia re-kreuje także własną prehistorię. W zachowaniu dziecka, znajdującego natychmiast nić porozumienia z psem, i wyglądem zewnętrznym przypominającego Natalię, znajdujemy zapowiedź jego lepszego losu. Bohaterka swym postępowaniem nie tylko czyni świat lepszym, ale uzdrawia także samą siebie. Dając sobie szansę na miłość, budzi się z duchowego odrętwienia. 
Ten ocalający powrót do samej siebie poprzedza etap teatralizacji, charakterystyczny - jak zauważa Swietłana Boym - dla zachowań nostalgicznych. Natalia, szukając recepty na życie, bierze udział w swoistej maskaradzie kobiecości, przymierza zaskakujące dla widza stroje (suknia ślubna, prowokacyjny czerwony kostium etc.) jak gdyby szukała roli dla siebie, testowała, czy utracone na zawsze niewykorzystane możliwości były rzeczywiście dla niej. Budzące skojarzenia z kiczem przebieranki przywodzą na myśl prace Cindy Sherman, jednej z czołowych artystek postmodernizmu, autorki słynnych Film Stills, serii fotografii, na których sama Sherman wciela się w uderzające sztucznością, stylizowane role kobiety współczesnej. Film Storożewej i kojarzoną $\mathrm{z}$ nurtem feministycznym sztukę Sherman można by uznać $\mathrm{w}$ tym kontekście za przykłady ersatz nostalgii, tęsknoty - jak wspomina Arjun Appadurai - sztucznie wytworzonej, dyktowanej potrzebą, której wcześniej nie było, wyprodukowanej przez sztukę masową [1996: 78]. W filmie Podróż ze zwierzętami domowymi potrzeba ta wyrasta z kontaktu z wcześniej niedostępnym dla Natalii światem zewnętrznym, który rodzi w niej chęć prowokacji, oderwania się od - na ten moment - ograniczającego życia wiejskiego. Irracjonalny epizod jazdy pociągiem i ryzykowne z niego wyskoczenie można odczytywać jako odrzucenie mirażu światowego życia, powrót do codzienności, w której Natalii przypisana została rola matki, opiekunki stwarzającej dom dla bezdomnych, syna i psa.

Zaproponowany wyżej sposób interpretacji pozwala wskazać na związek istniejący między omawianym filmem a obrazem Nostalgia (Hoстальгия, 1983) Andrieja Tarkowskiego. Mistrz rosyjskiego kina również wyraźnie stawia akcent na stabilną obecność matki, o czym świadczy psychiczne rozchwianie prowokacyjnej Eugenii, jej nerwowe wybuchy i desperacja, by uwieść głównego bohatera. Slavoj Žižek nazywa Eugenię "bytem wybrakowanym”, "nieautentycznym, histerycznym stworzeniem”, niekorzystnie skontrastowanym przez reżysera z matczyną figurą porzuconej w Rosji żony [2011: 215]. Žižek jednoznacznie komentuje:

Według Tarkowskiego w momencie, gdy kobieta akceptuje rolę osoby seksualnie pożądanej, poświęca to, co w niej najcenniejsze, duchową esencję jej istnienia, a zatem traci swoją wartość, przechodzi w jałowy modus egzystencji: świat Tarkowskiego jest przesiąknięty ledwie skrywanym obrzydzeniem do kobiety prowokacyjnej [2011: 215-216].

Bezpieczeństwo i autentyczność symbolizuje w Nostalgii drewniana dacza, pojawiająca się $\mathrm{w}$ marzeniach bohatera. W swym wysublimowanym obrazie reżyser adaptuje - jak zauważa wspomniany słoweński kulturoznawca typowy hollywoodzki schemat tworzenia pary (the couple), by zakamuflować prowadzoną z odbiorcą grę [Žižek 2011: 217]. Film Storożewej z przy- 
wołanym obrazem Tarkowskiego spinają w mentalną całość również długie ujęcia, dopuszczające zaledwie powolny ruch, sygnalizujące wyczekiwane duchowe pojednanie głównego bohatera ze światem, poddanie się sile inercji. Zewnętrzna podróż w obu obrazach to „eksternalizacja i/lub projekcja wewnętrznej podróży, podróży inicjacyjnej w głąb własnej psyche" [Žižek 2011: 217].

W próbie dołączenia Natalii do pasażerów pociągu można dostrzec nie tylko spektakl i maskaradę potencjalnych tożsamości kobiety, ale także akt wpisywania indywidualnego losu $\mathrm{w}$ zachowanie grupy, będące wyrazem zbiorowej nostalgii za przeszłością, by posłużyć się tutaj terminem Freda Davisa. Pociąg zdaje się w tej sekwencji być znakiem Rosji radzieckiej i życia odchodzącego w przeszłość wraz z jej upadkiem. Bohaterka, kierując się impulsem i wsiadając do pociągu, pragnie to życie w pewien sposób zatrzymać i uchwycić. Scena ta przypomina widzowi, że w kinie sowieckim pociąg niejednokrotnie symbolizował ideę postępu i modernizacji. W filmie Podróż ze zwierzętami domowymi znajdujemy komunikat pozwalający scalić ten obraz z dziełem Mała Wiera (Маленькая Вера, 1988) Wasyla Piczuła, w którym wspomniany środek transportu, przeważnie stojący na bocznicy, niesie w sobie zapowiedź unicestwienia dotychczasowego świata, nieuchronnych zmian w przededniu rozpadu Związku Radzieckiego, co zostaje zaakcentowane również w obrazie filmowym Taxi Blues.

Propozycja Pawła Łungina wydaje się koncentrować na kluczowej dla kultury rosyjskiej opozycji ja-my oraz relacji przeszłość-teraźniejszość. Swietłana Boym twierdzi, że „nostalgia nie jest wrogiem współczesności, lecz jej częścią składową", a tęsknota (algia) zawiera w sobie potencjał jednoczący, stąd narracje nostalgiczne mogą służyć tworzeniu się swoistych „wspólnot utraty". Irina Kaspe zauważa z kolei, że nostalgia to nie tylko sposób konstruowania przeszłości, ale także szczególna struktura tożsamości osobistej i zbiorowej [2008: 4].

Obraz „ja” bądź „my” w danym przypadku kształtują dwa jasno zaznaczone bieguny „teraźniejszości” i „przeszłości”, gdzie wewnętrzne cechy „teraźniejszości” mogą okazać się rozmyte i nieokreślone w porównaniu z "przeszłością", ale granice wewnętrzne są ściśle zaznaczone, bieguny dzieli znaczny dystans, wręcz przepaść [Zamarajewa 2014: 23].

W takim wypadku artykulacja doświadczenia przeszłości może służyć budowaniu przeszłości w oparciu o doświadczenia pozytywne i negatywne, budujące niepowtarzalny charakter wspólnoty, która dzięki temu procesowi może sobie z nimi poradzić [Yang 2003: 278-283]. W mojej opinii film Taxi blues potwierdza powyższe spojrzenie na kategorię nostalgii, można go uznać za przykład kina nostalgicznego, opowieść o mentalności rosyjskiej i odzyski- 
waniu przyszłości przez naród rosyjski drogą zanurzenia w przeszłość. Najbardziej emblematyczne pod tym względem są dwie sceny, których zderzenie buduje obraz utopijnej przeszłości i przyszłości jednocześnie. Mowa tu o ujęciu głównego bohatera Szłykowa w planie ogólnym, na tle charakterystycznego wieżowca z epoki stalinowskiej, gdy widzimy go czekającego przez noc na zapłatę za kurs. Maleńka sylwetka bohatera wskazuje, że jego determinacja i wiara w określone zasady zostają wówczas nie tylko poddane próbie. Monumentalność budowli nadaje postaci wymiar ironiczny, ukazuje bezsilność zarówno taksówkarza, jak i całego systemu, który legnie za chwilę w gruzach, co sugeruje wizualne skojarzenie obrazu z kolosem na glinianych nogach. Mocno stąpający po ziemi Szłykow, człowiek brutalny, o solidnej budowie zewnętrznej, kierujący się prymitywnymi instynktami, przegrywa w starciu z Lioszą, saksofonistą, wolnym duchem, nieprzywiązanym do nikogo i niczego, co zostaje podkreślone również w wyglądzie zewnętrznym muzyka, jego chudości i upodobaniu do używek. Kontrast ten, w zestawieniu z różnicą światopoglądów bohaterów, którzy budują zaskakujący dla widza rodzaj relacji osobistej, pozwala traktować film jako przykład rosyjskiego wariantu buddy movies, otwierając przy tym szereg nowych możliwości badawczych [Seckler 2009]. W kręgu niezrealizowanych $\mathrm{w}$ niniejszej publikacji interpretacji należałoby umieścić również potencjalne postępowanie, zmierzające do dostrzeżenia w Lioszy antybohatera naszych czasów, łączącego w sobie dystynktywne cechy zarówno wiecznego rosyjskiego fatalizmu, jak i amerykańskiego wiecznego optymizmu, manifestującego się w nadrzędnym umiłowaniu wolności.

Zapowiadane wyżej zestawienie wspomnianego ujęcia z kadrami ukazującymi fragment występu, promującego trasę koncertową Lioszy na telebimie, pozwala postawić tezę o dominacji sfery wirtualnej w życiu tego bohatera. Szłykow jawi się przy nim jako człowiek zamieszkujący przede wszystkim w regulowanej określonymi zasadami rzeczywistości fizycznej, podczas gdy Liosza, postrzegany przez część krytyków jako uosobienie antysemickich uprzedzeń Rosjan, funkcjonuje głównie dzięki wyobraźni pobudzanej muzyką. Świadczą o tym nie tylko halucynacje bohatera po wypiciu wody kolońskiej, kiedy to mentalnie, przy dźwiękach grającego w głowie saksofonu, przenosi się do sztucznego raju, ale także ścieżka rozwoju jego kariery. Powstały w 1990 roku film to obraz końca czasów sowieckich, kiedy Zachód stanowił przeważnie konstrukt mityczny, był światem zupełnie obcym i nieosiągalnym. Występujący na telebimie Liosza, którego kariera przypadkiem nabrała rozpędu za granicą, wkracza nagle i agresywnie w rzeczywistość rosyjską jako zupełnie inny człowiek. Nie bez znaczenia jest tutaj chyba również fakt, że Lioszę gra Piotr Mamonow, legendarny założyciel grupy rokowej Zvuki Mu, co przydając bohaterowi wiarygodności, narzuca jednocześnie asocjacje $\mathrm{z}$ mitem artysty, postacią-ikoną świata muzyki. W konsekwencji 
reprezentowany przez Lioszę świat komercyjnego sukcesu to dla Szłykowa rzeczywistość utopii, ziemia obiecana, kusząca mirażem bliskości.

Skarnawalizowana scena odwiedzin w mieszkaniu Szłykowa nie pozostawia jednak złudzeń, że jest to świat poza zakresem możliwości taksówkarza, pryska mit imperium i ulatnia się marzenie o powrocie do tego, co znane i oswojone, utożsamiane z obecnością Lioszy. W rezultacie można rzec, że kojarzona z improwizacją i wolnością muzyka jazzowa jest $\mathrm{w}$ filmie nośnikiem myślenia nostalgicznego, językiem emocji przywołującym wspomnienia, co pozostaje w zgodzie z obserwacjami Swietłany Boym, dotyczącymi ogólnej natury nostalgii, zamieszczonymi w monografii Przyszłość nostalgii (Future of nostalgia). Zwracając uwagę na dziewiętnastowieczną genezę zjawiska, Boym wskazuje na potencjał rytuału i wspomnień, które miały odwracać uwage od nieuchronności upływającego czasu, i akcentuje wagę kultury popularnej, sprzyjającej nostalgiotwórczej teatralizacji życia codziennego. Kluczową w tym kontekście wydaje się być kwestia pamięci, którą w triadzie tuż obok nostalgii i historii umieszczają w swych rozważaniach Emily Keightley i Michael Pickering. Postrzegając relację między elementami triady jako kontinuum, badacze definiują nostalgię jako ucieczkę od teraźniejszości, sprzężoną z pragnieniem powrotu do idealizowanej przeszłości i odzyskiwaniem przyszłości drogą uznania pewnych aspektów przeszłości za podstawę lepszej przyszłości [Pickering, Keightley 2006: 937]. Jest to więc forma „rezydencji kulturowej", związana z poszukiwaniem bezpieczeństwa ontologicznego w przeszłości, stanowiącej przy tym rodzaj drogowskazu, orientacyjnej mapy przyszłości. W ujęciu Łungina, z trzech elementów składających się na nostalgię, czyli tęsknoty, braku i utraty, zdaje się dominować ten ostatni obszar. Prześmiewcze zakończenie, bezproduktywny pościg samochodowy, wskazuje raczej na niemożność zaspokojenia tęsknoty niż na szansę odbudowy świata na zgliszczach historii.

Zaproponowana wyżej interpretacja współczesnych dzieł filmowych pozwoliła zauważyć, że w obu analizowanych tekstach artystycznych bohaterowie zmuszeni są funkcjonować w hybrydycznej rzeczywistości, na styku starego i nowego systemu. Rozpad otaczającego ich świata towarzyszy nostalgicznym dążeniom do odzyskania obrazu całości i utraconej tożsamości bohatera, który sprawdzając się w nieznanych dotychczas rolach szuka dla siebie miejsca w nowych okolicznościach życiowych. Składające się na nostalgię doświadczenie braku, tęsknota za innym życiem i utrata stabilnego punktu oparcia stają się $\mathrm{w}$ obu filmach motywacją do bycia w drodze, czynią bohaterów nomadami. Podróż ze zwierzętami domowymi akcentuje wymiar przestrzenny tych poszukiwań, reżyser Taxi Blues przekłada ów proces przede wszystkim na wizję relacji z czasem, płynne kontinuum przeszłości, teraźniejszości i przyszłości, odpowiadające triadzie historia-pamięć-nostalgia. 


\section{Bibliografia}

Бакина Т. В. 2014. Образ прошиого и ностальгическое переживание в кинематографе, Москва: Издательский дом Высшей школы экономики.

Каспэ И. 2008. Съесть прошиое. Идеология и повседневность гастрономической ностальгии, [w:] А. М. Никулин, Пути России: культура - общество - человек, Москва: Логос.

Appadurai A. 1996. Modernity at Large, Minneapolis: University of Minnesota Press.

Boym S. 2001. The Future of Nostalgia, źródło elektroniczne: https://sculptureatpratt. files.wordpress.com/2015/07/svetlana-boym-the-future-of-nostalgia.pdf (dostęp: 19.05.2017).

Czapliński P. 2001. Wzniosłe tęsknoty. Nostalgie w prozie lat dziewięćdziesiątych, Kraków: Wydawnictwo Literackie.

Davis F. 1979. Yearning for Yesterday: A Sociology of Nostalgia, New York: Free.

Hutcheon L. 2000. Irony, Nostalgia, and the Postmodern, źródło elektroniczne: http:/ /www. library.utoronto.ca/utel/criticism/hutchinp.html (dostęp: 19.05.2017).

Jameson F. 1982. Postmodernism and Consumer Society, źródło elektroniczne: http://art. ucsc.edu/sites/default/files/Jameson_Postmodernism_and_Consumer_Society.pdf (dostęp: 19.05.2017).

Maier Ch. S. 1999. The End of Longing? Notes toward a History of Postwar German National Longing, [w:] J. S. Brady, B. Crawford, S. E. Wiliarty (red.) The Postwar Transformation of Germany: Democracy, Prosperity, and Nationhood, Ann Arbor: University of Michigan Press.

Monastireva-Ansdell E. 2008. One Size Does Not Fit All: Trains, Fashions, Mammals, and the Meaning of Life in Vera Storozheva's "Traveling with Pets", źródło elektroniczne: http:/ / www.kinokultura.com/2008/19r-puteshestvie.shtml (dostęp: 19.05.2017).

Pickering M., Keightley E. 2006. The Modalities of Nostalgia, "Current Sociology", t. 54, nr 6.

Seckler D. A. 2009. Engendering Genre: the Contemporary Russian Buddy Film, źródło elektroniczne: http://d-scholarship.pitt.edu/10213/1/Diss_Seckler_2009.pdf (dostęp: 19.05.2017).

Yang G. 2003. China's Zhiqing Generation: Nostalgia, Identity, and Cultural Residence in the 1990s, „Modern China”, t. 29, nr 3.

Zamarajewa A. 2014. „W poszukiwaniu utraconych obrazów. Nostalgia postsowiecka w polityce symbolicznej Rosji", Warszawa [praca doktorska].

Žižek S. 2011. Lacrimae rerum. Kieślowski, Hitchcock, Tarkowski, Lynch, Warszawa: Wydawnictwo Krytyki Politycznej. 
